\title{
Comparative proteomics of the mixotrophic dinoflagellate Prorocentrum micans growing in different trophic modes
}

\author{
Junbo Shim¹, Tatyana A. Klochkova' ${ }^{1}$ Jong Won Han ${ }^{1}$, Gwang Hoon Kim ${ }^{1, *}$, Yeong Du Yoo ${ }^{2}$ \\ and Hae Jin Jeong ${ }^{2}$
}

${ }^{1}$ Department of Biology, Kongju National University, Kongju 314-701, Korea

${ }^{2} S c h o o l$ of Earth and Environmental Sciences, College of Natural Sciences, Seoul National University, Seoul 151-747, Korea

Protein profiles of a common mixotrophic dinoflagellate, Prorocentrum micans, growing autotrophically and mixotrophically (fed on the cryptophyte Rhodomonas salina) were compared using two-dimensional gel electrophoresis (2$\mathrm{DE})$ to determine if they vary in different trophic modes. Approximately $2.3 \%$ of the detected proteins were differentially expressed in the different trophic modes. Twelve proteins observed only in the mixotrophic condition had lower pI value $(<5)$ than the fifteen proteins observed only in the autotrophic condition $(>5)$. When the internal amino acid sequences of five selected proteins differentially expressed between autotrophic and mixotrophic conditions were analyzed using matrix-assisted laser desorption time-of-flight (MALDI-TOF) mass spectrometry, two proteins that were specifically expressed in the autotrophic condition showed homology to glyceraldehyde-3-phosphatase dehydrogenase (GAPDH) and a bacterial catalase. Three mixotrophy-specific proteins showed homology to certain hypothetical proteins from an insect and bacteria. These results suggested the presence of certain gene groups that are switched on and off according to the trophic mode of P. micans.

Key Words: cryptophyte; feeding; mixotrophy; Prorocentrum micans; proteomic; Rhodomonas salina

\section{INTRODUCTION}

Marine dinoflagellates are ubiquitous and some genera are cosmopolitan (Smayda 1997, Jeong 1999). These organisms often dominate plankton assemblages and sometimes form red tides or harmful blooms (Jeong 1999). Marine dinoflagellates have three different major trophic modes, autotrophic, mixotrophic, and heterotrophic. Recently, many phototrophic dinoflagellates that had previously been thought to be exclusively autotrophic were found to be mixotrophic (Bockstahler and Coats 1993, Jacobson and Anderson 1996, Skovgaard 1996, Stoecker 1999, Jeong et al. 2005, Seong et al. 2006). The prey organisms that these mixotrophic dinoflagel- lates are able to feed on are quite diverse and include bacteria, diverse algae, other dinoflagellates, and heterotrophic protists (Stoecker 1999, Burkholder et al. 2008).

Although there have been many studies on the ecology and taxonomy of these mixotrophic dinoflagellates (Jeong et al. 2005), only a few have investigated their proteomics (Wang et al. 2009). When a culture of dinoflagellates is established by single cell isolation, all individual cells have the same genome; however, if a dinoflagellate grows in various nutritional modes (autotrophically or mixotrophically), their gene expression may change. Differences in gene expression depending on trophic mode (c) This is an Open Access article distributed under the terms of the Creative Commons Attribution Non-Commercial License (http://creativecommons.org/licenses/by-nc/3.0/) which permits unrestricted non-commercial use, distribution, and reproduction in any medium, provided the original work is properly cited.
Received 23 January 2011, Accepted 24 February 2011

*Corresponding Author

E-mail: ghkim@kongju.ac.kr

Tel: +82-41-850-8504 Fax: +82-41-850-8479 
imply that the expression of genes involved in feeding and photosynthesis may be switched on and off, which could influence the cost of producing proteins. Therefore, a comparative approach to developing protein profiles of mixotrophic dinoflagellates growing autotrophically and mixotrophically is very important.

Proteomics using large two-dimensional polyacrylamide gel electrophoresis (2-DE) allows multiple expressed proteins to be separated and mapped, providing a convenient and powerful method for monitoring variations at translational levels (Kim et al. 2008). Proteins identified using peptide mass fingerprinting (PMF) and tandem mass spectrometry (MS/MS) ion searches can be separated and then analyzed by MS/MS. Proteomic technology is thus useful for investigating the correlation between expressed proteins and behavioral and physiological phenotypes during biological cycles (Akimoto et al. 2004). However, these techniques have seldom been used in the field of marine biology because of the poor reproducibility of the results caused by heavy polysaccharides contained in algae. Recently, a rapid progress has been made in 2-DE methodology for marine algae. Chan et al. (2002) first reported a method for the optimization of sample preparation for 2-DE and later conducted proteomic analysis for species recognition of several harmful bloom-related dinoflagellates (Chan et al. 2004, 2006). More recent studies have shown that 2 -DE results are useful for analysis of the phylogenetic relationships among closely related species of algae (Kim et al. 2008).

To determine if the mixotrophic dinoflagellate Prorocentrum micans Ehrenberg has different protein profiles when it grows autotrophically or mixotrophically by feeding on the cryptophyte Rhodomonas salina (Wislouch) Hill et Wetherbee, we compared the protein profiles obtained during two nutritional modes using 2-DE with highly reproducible results for quantification analysis. In addition, the protein profiles of $P$. micans growing autotrophically for 2 weeks after feeding on R. salina for 1 month (mixotrophic-autotrophic transition condition) were analyzed. Also, the internal amino acid sequences of five protein spots that were differentially expressed between autotrophic and mixotrophic conditions were analyzed using an Ettan matrix-assisted laser desorption ionization time-of-flight (Ettan ${ }^{\mathrm{TM}}$ MALDI-TOF) mass spectrometry. The results of the present study provide a basis for the expression proteomes of mixotrophic dinoflagellates obtained under different nutritional modes.

\section{MATERIALS AND METHODS}

\section{Preparation of experimental organisms}

The mixotrophic dinoflagellate P. micans (PMCJH99) and cryptophyte $R$. salina were grown at $20^{\circ} \mathrm{C}$ in enriched f/2 seawater medium (Guillard and Ryther 1962) without silicate under $14: 10 \mathrm{~h} \mathrm{~L}$ : D cycles with $20 \mu \mathrm{mol}$ photons $\mathrm{m}^{-2} \mathrm{~s}^{-1}$ provided by cool-white fluorescent bulbs.

\section{Feeding process}

The initial concentrations of $P$. micans (ca. 10,000 cells $\mathrm{mL}^{-1}$ ) and R. salina (ca. 100,000 cells $\mathrm{mL}^{-1}$ ) were established using an auto pipette to deliver predetermined volumes of the culture with known cell densities to the experimental bottles. One $80-\mathrm{mL}$ polycarbonate (PC) bottle (mixtures of P. micans and R. salina) was set up. The bottle was filled to capacity with freshly filtered seawater, capped, and then well mixed. After 6, 12, and 24 $\mathrm{h}$ incubations, a $5-\mathrm{mL}$ aliquot was removed from each bottle and transferred to a 10-mL bottle. In addition, two $0.1-\mathrm{mL}$ aliquots were placed on slides and cover-glasses were added. These conditions resulted in the dinoflagellate predator cells being alive, but almost motionless. The behavior of over 100 unfed P. micans cells was then observed under the microscope at a magnification of $100 \times$, which enabled all of the feeding processes from the time a prey cell was captured to the time that it was engulfed by a predator to be seen. A series of pictures showing the feeding process for $P$. micans cell were then taken using a video analysis system (Sony DXC-C33; Sony Co., Tokyo, Japan) mounted on an epifluorescence microscope at a magnification of $100 x$.

\section{Transmission electron microscopy}

For transmission electron microscopy (TEM), predator and / or prey cells were fixed for $1.5-2 \mathrm{~h}$ in $2.5 \%(\mathrm{v} / \mathrm{v})$ glutaraldehyde in culture medium. The cells were then centrifuged, after which the pellet was embedded in $1 \%$ agar $(w / v)$. After several medium rinses, the cells were post fixed in $1 \%(\mathrm{w} / \mathrm{v})$ osmium tetroxide with deionized water. Dehydration was accomplished using a graded ethanol series (i.e., 5060708090 and 100\% ethanol, followed by two $100 \%$ ethanol steps). The material was then embedded in Spurr's low-viscosity resin (Spurr 1969). Sections were obtained using a RMC MT-XL ultramicrotome (Boeckeler Instruments Inc., Tucson, AZ, USA) and post stained with $3 \%(\mathrm{w} / \mathrm{v})$ aqueous uranyl acetate followed by lead citrate. The stained sections were viewed using a JEOL-1010 electron microscope (Jeol Ltd., Tokyo, Japan). 


\section{Chemicals and reagents}

Urea, thiourea, 3-[(3-cholamidopropyl)dimethylammonio]-1-propanesulfonate (CHAPS), dithiothreitol (DTT), benzamidine, Bradford solution, acrylamide, iodoacetamide, bis-acrylamide, sodium dodecyl sulfate (SDS), acetonitrile, trifluoroacetic acid, $\alpha$-cyano-4-hydroxycinnamic acid (CHCA), sodium bicarbonate, and ammonium bicarbonate were purchased from Sigma (St. Louis, MO, USA). Pharmalyte ( $\mathrm{pH}$ 3.5-10) was purchased from Amersham Biosciences (Piscataway, NJ, USA) and IPG DryStrips (pH 4-10NL, $24 \mathrm{~cm}$ ) were purchased from Genomine, Inc. (Pohang, Korea). Modified porcine trypsin (sequencing grade) was purchased from Promega (Madison, WI, USA).

\section{Protein sample preparation}

Experiment 1 was designed to determine if $P$. micans has different protein profiles in different trophic modes. Using large 2-DE, we measured the protein profiles of $P$. micans growing under autotrophic, mixotrophic, and mixotrophic-autotrophic transition conditions.

For the autrotrophic condition, approximately $1 \mathrm{~L}$ of a dense culture of $P$. micans (concentration = 10,000-15,000 cells $\mathrm{mL}^{-1}$ ) growing autotrophically for over one month was transferred into one of three 10 -L PC bottles that each contained $9 \mathrm{~L}$ of $\mathrm{f} / 2$ medium. Before experiment 1 was conducted, $P$. micans had been maintained under these conditions for over two months.

For the mixotrophic condition, approximately $3 \mathrm{~L}$ of a dense culture of $P$ micans (concentration $=10,000$ 15,000 cells $\mathrm{mL}^{-1}$ ) growing autotrophically for over one month was transferred into one of three 10-L PC bottles that each contained $3 \mathrm{~L}$ of $\mathrm{f} / 2$ medium. Approximately 5 $\mathrm{mL}$ of a dense culture of $R$. salina (concentration = ca. 100,000-120,000 cells $\mathrm{mL}^{-1}$ ) grown autotrophically for over one month was then added to one of the PC bottles every other day. P. micans nearly completely eliminated $R$. salina cells during the intervals. Prior to conducting experiment 1, P. micans had also been maintained for over two months under these conditions. When prey cells were undetected, the experiment was initiated.

For the mixotrophic-autotrophic transition condition, approximately $1 \mathrm{~L}$ of a dense culture of $P$. micans (concentration $=10,000-15,000$ cells $\mathrm{mL}^{-1}$ ) growing mixotrophically for about 1 month as described above was transferred into one of three 10-L PC bottles, which each contained $9 \mathrm{~L}$ of $\mathrm{f} / 2$ medium. Before experiment 1 was conducted, P. micans was grown autotrophically for two weeks.

P. micans cells growing under autotrophic, mixotrophic, and autotrophic-mixotrophic transition conditions were separated and centrifuged in the medium solution. The supernatants were then removed and the pellets were washed twice with ice-cold phosphate buffered saline (PBS) solution, after which they were sonicated for 10 s using Sonoplus (Bandelin Electronic, Berlin, Germany). The pellets were then homogenized directly using a motor-driven homogenizer (PowerGen125; Fisher Scientific, Pittsburgh, PA, USA) in sample lysis solution composed of $7 \mathrm{M}$ urea, $2 \mathrm{M}$ thiourea containing $4 \%$ (w/v) CHAPS, $1 \%(\mathrm{w} / \mathrm{v})$ DTT, $2 \%(\mathrm{v} / \mathrm{v})$ pharmalyte, and $1 \mathrm{mM}$ benzamidine. Freezing and thawing of the samples was repeated five times over one day. Occasionally, a bead beater was used to facilitate lysis of the cells. The proteins were then extracted for $1 \mathrm{~h}$ at room temperature by vortexing. After centrifugation at $15,000 \mathrm{~g}$ for $1 \mathrm{~h}$ at $15^{\circ} \mathrm{C}$, insoluble material was discarded and the soluble fraction was used for 2-DE. Protein loading was normalized using a Bradford assay (Bradford 1976).

\section{Two-dimensional polyacrylamide gel electro- phoresis}

Immobilized pH gradient (IPG) dry strips were equilibrated for 12-16 h with $7 \mathrm{M}$ urea, $2 \mathrm{M}$ thiourea containing $2 \%$ CHAPS, $1 \%$ DTT, and $1 \%$ pharmalyte and then loaded with $200 \mu \mathrm{g}$ of sample. Isoelectric focusing (IEF) was conducted at $20^{\circ} \mathrm{C}$ using a Multiphor II electrophoresis unit and an EPS 3500 XL power supply (Amersham Biosciences) following the manufacturer's instructions. For IEF, the voltage was linearly increased from 150 to $3,500 \mathrm{~V}$ over $3 \mathrm{~h}$ for sample entry followed by a constant 3,500 V, with focusing complete after $96 \mathrm{kVh}$. Prior to the second dimension, strips were incubated for $10 \mathrm{~min}$ in equilibration buffer (50 mM Tris-Cl, pH 6.8 containing $6 \mathrm{M}$ urea, $2 \%$ SDS, and $30 \%$ glycerol), first with $1 \%$ DTT and then with $2.5 \%$ iodoacetamide. The equilibrated strips were inserted onto SDS-polyacrylamide gel electrophoresis (SDS-PAGE) gels $(20 \times 24 \mathrm{~cm}, 10-16 \%)$ and SDS-PAGE was performed using a Hoefer DALT 2-DE system (Amersham Biosciences) following the manufacturer's instructions. 2-DE gels were run at $20^{\circ} \mathrm{C}$ for $1,700 \mathrm{Vh}$, then stained using Coomassie Brilliant Blue G 250.

\section{Image analysis}

Quantitative analysis of digitized images was conducted using the PDQuest version 7.0 software (BioRad, 
Hercules, CA, USA) according to the manufacturer's protocols. The quantity of each spot was normalized using the total valid spot intensity. Protein spots were considered to have significant expression when the variation deviated by more than two-fold when compared with the control or normal sample.

\section{Enzymatic digestion of proteins}

Protein spots were enzymatically digested in-gel in a manner similar to the method described by Shevchenko et al. (1996) using modified porcine trypsin (Promega modified). Gel pieces were washed with $50 \%$ acetonitrile to remove SDS, salt, and stain. Washed and dehydrated spots were then vacuum dried to remove the solvent and rehydrated with trypsin solution (8-10 $\mathrm{ng} \mu \mathrm{L}^{-1}$ ) in $50 \mathrm{mM}$ ammonium bicarbonate at $\mathrm{pH} 8.7$, after which they were incubated for $8-10 \mathrm{~h}$ at $37^{\circ} \mathrm{C}$.

\section{Mass spectrometry}

All MS and power spectral density (PSD) spectra were acquired in the positive ion mode using an Ettan MALDI-TOF (Amersham Biosciences) mass spectrometer equipped with a pulsed extraction source, a 337$\mathrm{nm}$ pulsed nitrogen laser and a curved-field reflectron. The acceleration voltage was $20 \mathrm{kV}$. The CHCA matrix was prepared in $1: 1$ acetonitrile / water. A thin layer of the matrix was first applied onto the sample plate, after which $0.5 \mu \mathrm{L}$ of sample and $0.5 \mu \mathrm{L}$ of matrix were applied and the sample was allowed to dry at room temperature.

\section{Protein identification using chemically assisted fragmentation (CAF)-MALDI data}

Experiment 2 was designed to identify the proteins. The fragment masses obtained from CAF-MALDI were submitted to Sonar in the Ettan MALDI-TOF software or similar protein identification search engines (e.g., Pepfrag). The mass of the native (non-derivatized) peptide and five fragment masses or more (depending on the protein) were used for protein identification. The amino acid sequence of the peptide can be obtained from the distances between consecutive peaks (y-ions) in the PSD spectrum. By submitting the amino acid sequence, the protein can be identified by a homology search using ProteinInfo ${ }^{\mathrm{TM}}$ (www.proteometrics.com), or with a BLAST search using the ExPASy Molecular Biology Server (www.expasy.ch).

\section{RESULTS}

P. micans fed on R. salina prey by engulfing the prey cell through sutures on the sides of their body (Fig. 1A \& B). One or two ingested prey cells were observed inside the protoplasm of each predator cell when observed under an epifluorescence microscope or TEM (Fig. 1C-G).

Approximately 1,200 protein spots were observed in each 2-DE gel during the five trials using the same experimental setting (Fig. 2). Overall, 27 protein spots were differentially expressed consecutively in the two trophic modes (Fig. 3). Of these 27 spots, 12 that were observed under only the mixotrophic conditions had an isoelectric point below pI 5.0, while 15 protein spots that were observed in only the autotrophic conditions had a pI value above 5.0.

Eight protein spots that showed differences in quantity by trophic mode more than four times were selected for further analysis. Three proteins were only expressed in one trophic mode; 6404R under autotrophic conditions and 0133R and 1105R under mixotrophic conditions (Table 1). The profiles of the selected proteins in $P$. micans growing autotrophically for two weeks after feeding on R. salina for one month (mixotrophic-autotrophic transition condition) were also analyzed. Under mixotrophic-autotrophic transition conditions, six of the selected proteins were expressed in medium quantities, but two of the mixotrophy-specific proteins did not appear. The selected spots were isolated from the gel and their internal sequence was analyzed by CAF-MALDI mass spectrometry. The internal peptide sequence was successfully obtained for five of the spots (Table 2). Homology searches against the NCBI non-redundant (NCBI 2011), Swiss-Prot and TrEMBL databases identified similar proteins (Table 2). Two proteins (6404R and 5211R) specifically expressed under autotrophic condition showed homology to glyceraldehyde-3-phosphatase dehydrogenase (GAPDH) and catalase from Candidatus Nitrospira defluvii and Sphingomonas sp., respectively. Three mixotrophy-specific proteins showed homology to certain hypothetical proteins from an insect (0128R) and bacteria (0609R and 1105R), respectively.

\section{DISCUSSION}

Mixotrophic dinoflagellates are able to feed on prey and / or conduct photosynthesis (Stoecker 1999). Many proteins produced by these organisms are likely to be involved in photosynthesis and / or feeding as enzymes 

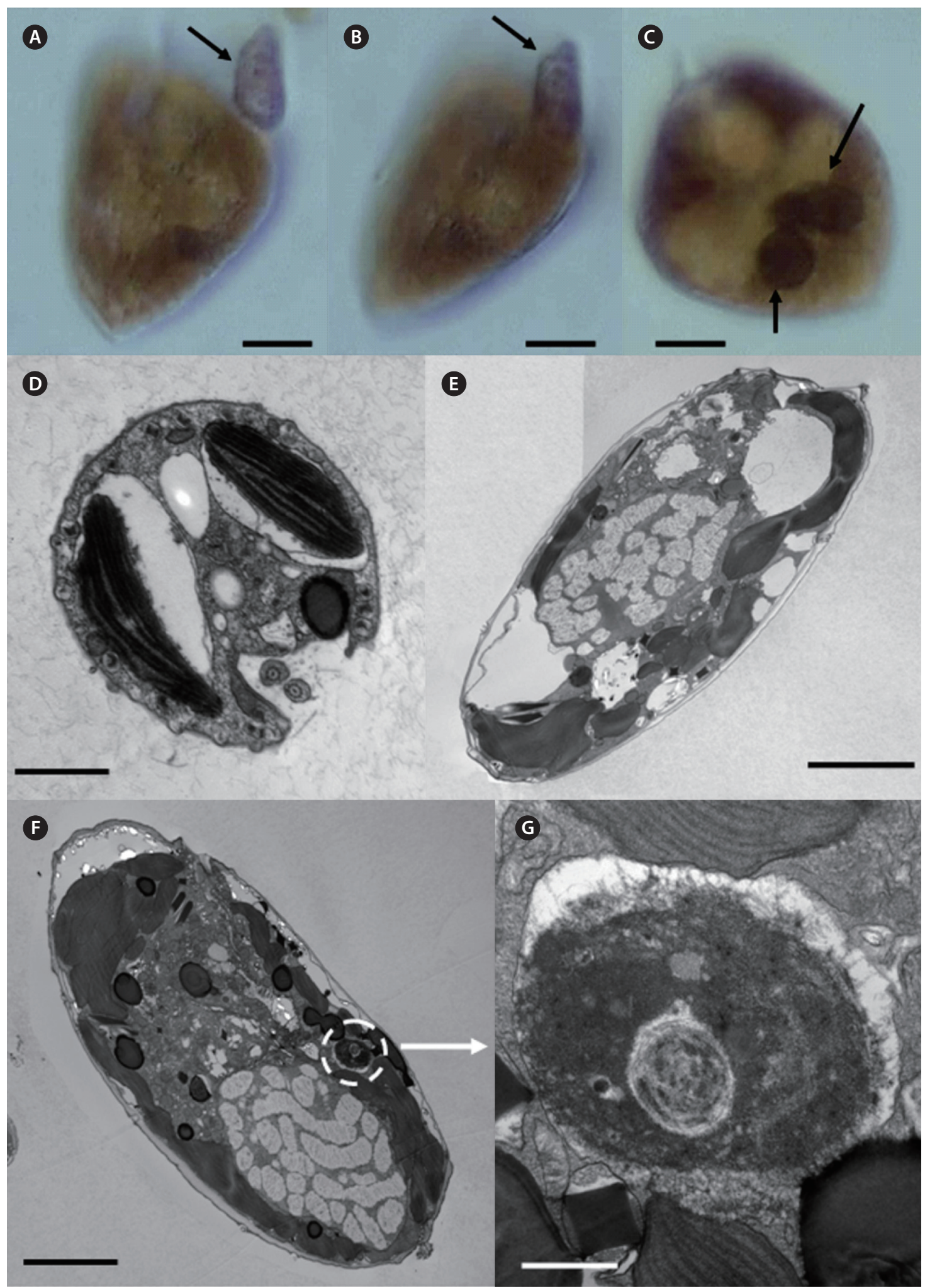

Fig. 1. Epifluorescence and transmission electron micrographs of Rhodomonas salina and Prorocentrum micans. (A) P. micans has captured $R$. salina cell through the suture. (B) P. micans has engulfed approximately $1 / 2$ of the body of $R$. salina cell. (C) $P$. micans contains two ingested $R$. salina cells. Arrows indicate $R$. salina cell. (D) Transversely sectioned $R$. salina cell. (E) Longitudinally sectioned P. micans cell. (F) P. micans cell with an ingested $R$. salina cell (dashed circle). (G) Enlargement from (F) showing the ingested $R$. salina cell inside the food vacuole of $P$. micans. Scale bars represent: A-C, $10 \mu \mathrm{m} ; \mathrm{D}, 1.0 \mu \mathrm{m} ; \mathrm{E} \& \mathrm{~F}, 5.0 \mu \mathrm{m} ; \mathrm{G}, 0.5 \mu \mathrm{m}$. 

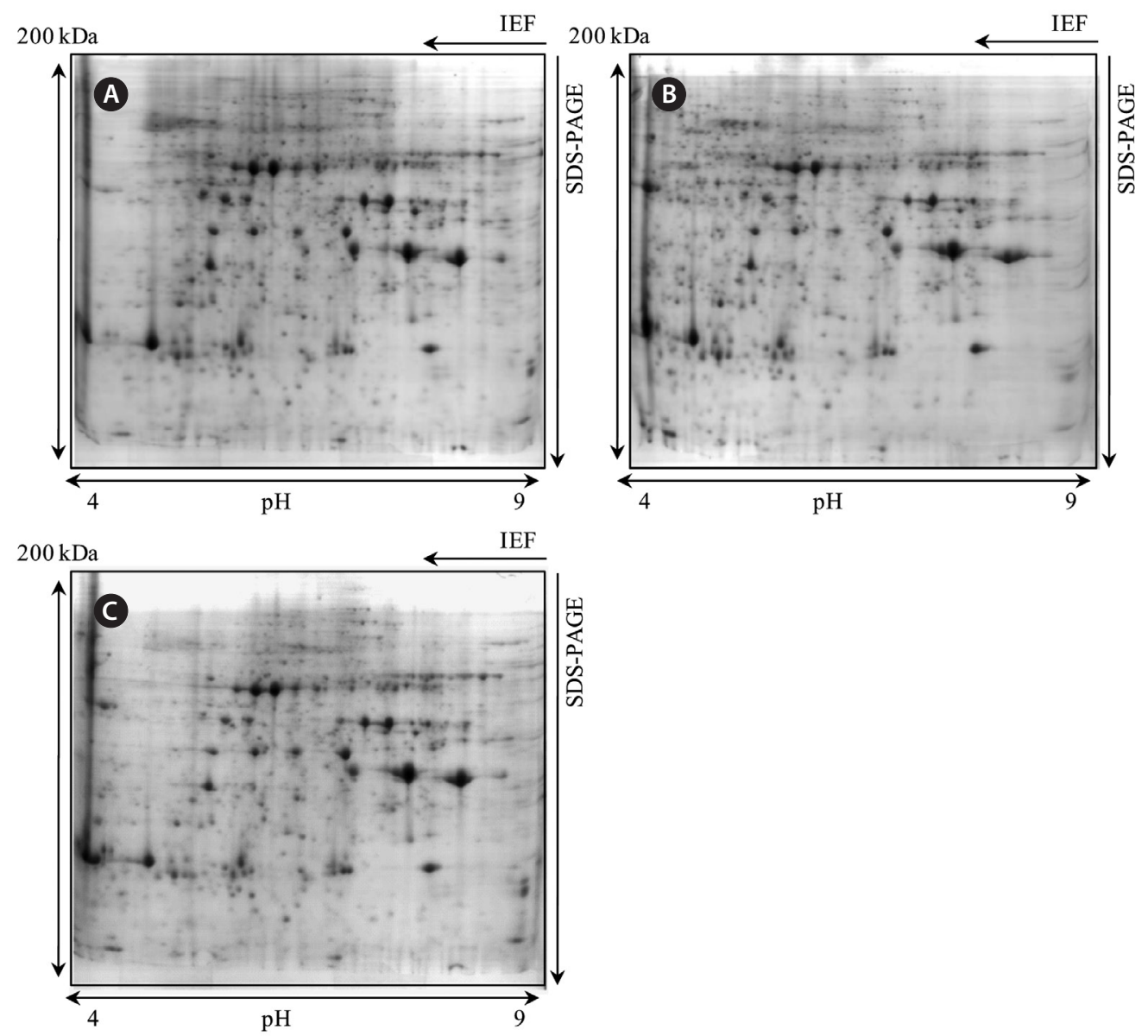

Fig. 2. Two dimensional electrophoresis gel images of Prorocentrum micans growing under autotrophic (A), mixotrophic (B), and mixotrophicautotrophic transition conditions (C). IEF, isoelectric focusing; SDS-PAGE, sodium dodecyl sulfate-polyacrylamide gel electrophoresis.

Table 1. Comparison of selected protein spots in mixotrophic (Mixo) and autotrophic (Auto) isolates and in isolates transferred from mixotrophic to autotrophic condition (Mixo-auto)

\begin{tabular}{lccccc}
\hline $\begin{array}{c}\text { Protein } \\
\text { spot ID }\end{array}$ & $\begin{array}{c}\text { Molecular weight } \\
(\mathbf{k D a})\end{array}$ & $\begin{array}{c}\text { Isoelectric point } \\
(\mathrm{pI})\end{array}$ & $\begin{array}{c}\text { Mixo } \\
\text { (relative quantity) }\end{array}$ & $\begin{array}{c}\text { Mixo-auto } \\
\text { (relative quantity) }\end{array}$ & $\begin{array}{c}\text { Auto } \\
\text { (relative quantity) }\end{array}$ \\
\hline $6404 \mathrm{R}$ & 41.82 & 6.27 & 0 & 683.2 & $1,220.4$ \\
$5211 \mathrm{R}$ & 31.49 & 5.66 & 114.2 & 169.6 & $1,256.7$ \\
9105 & 16.49 & 9.87 & 748.7 & $2,180.6$ & $3,289.1$ \\
$0118 \mathrm{R}$ & 20.36 & 4.23 & $2,818.9$ & $2,081.2$ & 669.3 \\
$0128 \mathrm{R}$ & 16.15 & 4.37 & $1,532.8$ & $1,121.3$ & 343.5 \\
$0609 \mathrm{R}$ & 64.10 & 4.25 & $2,300.8$ & 611.5 & 315.6 \\
$0133 \mathrm{R}$ & 17.57 & 4.31 & $1,573.4$ & 0 & 0 \\
$1105 \mathrm{R}$ & 17.80 & 4.52 & 930.9 & 0 & 0 \\
\hline
\end{tabular}

and some proteins are expected to be expressed differentially according to trophic modes. If photosynthesis stops during feeding, the mixotrophic condition is the same as a heterotrophic condition. There are five possibilities for gene expression with nutritional modes in mixotrophic dinoflagellates.

A dinoflagellate growing photosynthetically also produces the same proteins that it produces when growing 


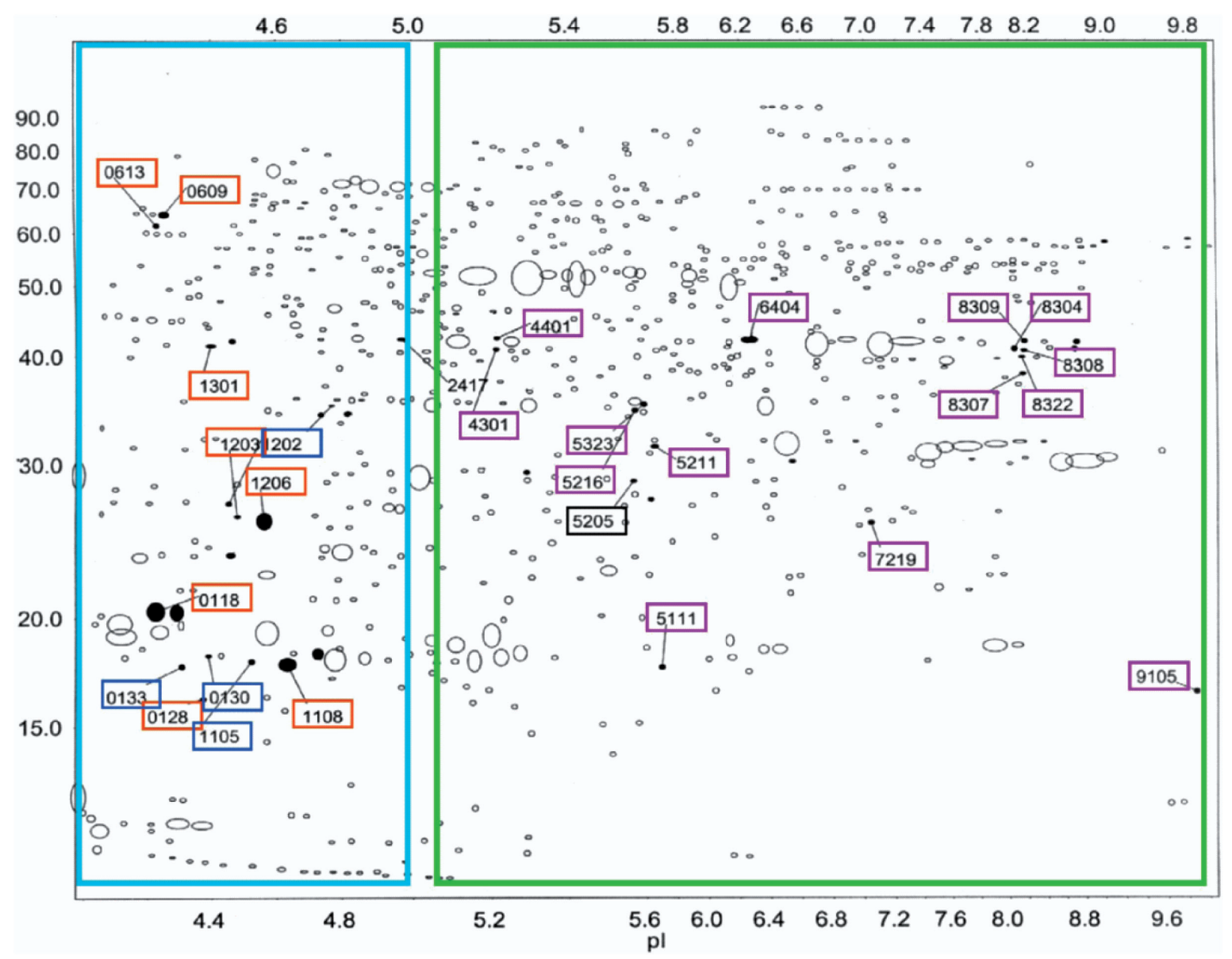

Fig. 3. Master diagram of the expression-proteome from 2-DE gel images of Prorocentrum micans growing in different trophic modes. Orange colored boxes indicate the protein spots expressed dominantly in mixotrophic isolates, blue colored boxes indicate the protein spots appearing only in mixotrophic isolates, purple colored boxes indicate the protein spots appearing dominantly in autotrophic isolates, and the black box indicates a protein spot appearing only in an autotrophic isolate. 2-DE, two-dimensional gel electrophoresis.

Table 2. Internal sequences of selected proteins determined by MALDI-mass spectrometry and similar proteins identified in protein databases

\begin{tabular}{lllll}
\hline Spot ID & Sequence & Identification / Sequence identity (\%) & Specificity & Species sharing homology \\
\hline 6404R & NTAWYNNEWGY & $\begin{array}{c}\text { Glyceraldehyde-3-phosphate } \\
\text { dehydrogenase / } 9 / 10(90 \%)\end{array}$ & Autotrophic & Candidatus Nitrospira defluvii \\
5211R & GPAPHANYEAPNAWGR & Catalase / 10/14 $(71 \%)$ & Autotrophic & Sphingomonas sp. \\
0128R & GTYGYCGYPGSGGW & Hypothetical protein / 8/8 $(100 \%)$ & Mixotrophic & Acyrthosiphon pisum \\
0609R & SSGHAATAGER & Hypothetical protein / $/ 11(81 \%)$ & Mixotrophic & Burkholderia cenocepacia \\
1105R & WNWCSGQSGSR & Hypothetical protein / $/ 10(80 \%)$ & Mixotrophic & Polaromonas naphthalenivorans \\
\hline
\end{tabular}

MALDI, matrix-assisted laser desorption ionization.

mixotrophically. In this case, there may be no switching on and off between nutritional modes and the cost of producing all proteins may be high because the dinoflagellate produces some proteins that do not function as well.

As an extreme case, a dinoflagellate growing photosynthetically does not produce any proteins that it produces when growing mixotrophically. Conversely, the dinofla- 
gellate growing mixotrophically also does not produce any proteins that it produces when growing photosynthetically. In this case, there may be strong switching on and off in the expression of genes related to photosynthesis and feeding and digestion; thus, the cost of producing proteins may be minimal. In this case, the dinoflagellate completely stops photosynthesis while feeding on prey.

A dinoflagellate growing photosynthetically does not produce some proteins that it produces when growing mixotrophically. Conversely, a dinoflagellate growing mixotrophically does not produce some proteins that it produces when growing photosynthetically. In this case, there may also be moderate switching on and off in the expression of genes related to photosynthesis and feeding and digestion; thus, the cost of producing proteins may be moderate.

While a dinoflagellate growing mixotrophically produces all of the proteins that are produced when growing photosynthetically, the dinoflagellate growing photosynthetically does not produce several proteins that it produces when growing mixotrophically. In this case, there may be switching on and off in the expression of genes related only to feeding and digestion and thus the cost of producing proteins may be moderate. When this occurs, the dinoflagellate produces proteins involved in feeding and digestion only during feeding (i.e., under mixotrophic conditions). In addition, this dinoflagellate may conduct photosynthesis while feeding.

While a dinoflagellate growing photosynthetically produces all of the proteins that it produces when growing mixotrophically, during mixotrophic growth the proteins produced when growing photosynthetically are not produced. In this case, there may be switching on and off in the expression of genes related only to photosynthesis and thus the cost of producing proteins may be moderate. This type of dinoflagellate produces proteins involved in feeding and digestion when growing both photosynthetically and mixotrophically. However, this type of dinoflagellate may stop photosynthesis when feeding on prey.

The present results support the fourth scenario, because some protein spots were observed under only mixotrophic conditions, while other protein spots were observed under only autotrophic conditions. The protein spots observed under only mixotrophic conditions are likely to be involved in feeding and the digestion of prey. The presence of the spots observed under only autotrophic conditions suggests that the activity of some enzymes involved in photosynthesis is largely depressed or stopped under mixotrophic conditions. Moreover, the results of the analysis of the protein spots by Ettan MALDI-TOF mass spectrometry revealed that the quantity of many proteins is likely to change depending on the trophic modes. This evidence suggests that there may be switching on and off of the expression of certain genes of P. micans depending on the trophic mode. The presence of this switch may reduce the cost of producing proteins in each trophic mode. However, only 27 proteins out of ca. 1,200 proteins $(2.3 \%)$ were differentially expressed between autotrophic and mixotrophic conditions. Of these 27 proteins, 12 were observed only under mixotrophic conditions. Therefore, $P$. micans requires only a few additional proteins to feed on algal prey. Kim et al. (2008) reported that $3.7-7.1 \%$ of the expression proteome (33-59 protein spots) was differentially expressed between male and female plants of the red algae, Bostrychia radicans and B. moritziana. These results suggests that the changes in a small portion of the expression proteome could significantly alter the morphological and physiological state of algal cells.

It is important to note that most of the mixotrophyspecific proteins had isoelectric points below pI 5.0, while all of the autotrophy-specific proteins had pI values over 5.0. These findings suggest that the $\mathrm{pH}$ of the cytoplasm changes with the trophic mode, which could control the activity of specific proteins involved in different trophic modes.

Proteomics is a rapidly growing field for the detection, identification and comparison of protein profiles in different organisms, tissues and / or conditions. In the present study, we were able to maintain constant culture conditions, and the clonal culture ensured the consistency of genotypes between trails, as well as the easy exclusion of all of the prey cells using filtration minimized contamination of the protein profiles. Without these precautions, e.g., with field-collected samples, analysis would have been problematic.

For proteome analysis, the inconvenience of working with algal species, which are poorly represented in genomic and proteomic databases, lies mostly in the lack of information regarding the cellular functions of the proteins identified (Kim et al. 2008). Although we were able to identify five proteins specific to trophic modes by homology searches against the protein databases the true nature and function of the proteins is still uncertain because of the lack of genetic information regarding dinoflagellates. Three mixotrophy-specific proteins showed homology with hypothetical proteins that have completely unknown functions. Two autotrophy-specific proteins showed homology to certain known genes. One 
of these proteins (5211R) was homologous with catalase from Sphingomonas sp., but we were unable to find any related references describing the function of the protein. Another protein (6404R) specifically expressed under autotrophic conditions was homologous with GAPDH from Candidatus Nitrospira defluvii. The obtained internal sequence contained the conserved domain of the gene. The GAPDH gene is an enzyme involved in the glycolytic pathway, which reversibly catalyses oxidative phosphorylation of D-glyceraldehyde-3-phosphate to form 1,3-diphosphoglycerate in the presence of nicotinamide adenine dinucleotide and inorganic phosphate (Harris and Waters 1976). This enzyme is widely distributed in nature in a variety of species ranging from bacteria to humans (Fothergill-Gilmore and Michels 1993). It is mainly found in the cytosol, the mitochondria, and the chloroplasts. Organelle GAPDHs are encoded by nuclear genes as precursor polypeptides and post-translationally imported into the organelles (Cerff 1995). This enzyme has been well characterized due to its central role in the intermediary metabolism, as well as its abundance and ease of preparation. The ubiquitous nature and evolutionary conservation of GAPDH indicate that it has a highly important physiological function. In addition to its well-characterized glycolytic activity, a housekeeping function essential for the normal metabolism of all cells, there is now accumulating evidence that this protein is involved in a wide variety of cellular functions (Sirover 1999). Accordingly, it was surprising that our data showed that this gene was switched off under mixotrophic condition. Further molecular studies are necessary to identify the isotypes of these proteins and their function under various nutritional conditions.

The process of protein solubilization is a critical step in 2-DE. The effectiveness of solubilization depended on the choice of the cell disruption method, protein concentration, choice of detergents, and composition of the sample solution. For this process, we used a modification of the process originally described by O'Farrell (1975). The solubilization of proteins improved when we washed the materials three times with distilled water before pulverization and used a lysis solution. Wong et al. (2006) reported that the phenol / chloroform protein extraction method gave better 2-DE resolution than the lysis buffer extraction for Gracilaria changii. We did not use the phenol / chloroform protein extraction in this study because the lysis solution we used provided satisfactory resolution for analysis and reduced sample preparation steps. As the composition of the lysis solution used by Wong et al. (2006) was different from ours it is difficult to conclude which method is better.

The present data showed that comparative proteomics may be a useful tool for analysis of the mixotrophism of dinoflagellates. With more standardized methods of protein extraction and consistent culture conditions this new tool could have a profound influence on studies of the cellular responses of dinoflagellates to environmental changes.

\section{ACKNOWLEDGEMENTS}

We thank Kyeong Ah Seong, Jae Seong Kim, Nam Seon Kang, and Jae Yoon Song for technical assistance. This study was supported by a grant from the Korean Research Foundation (2007-070-C00789), KOSEF (R01-2008-00010468-0) to HJJ and by a grant from the Ministry of Education and Science (KRF 20100020701) to GHK.

\section{REFERENCES}

Akimoto, H., Wu, C., Kinumi, T. \& Ohmiya, Y. 2004. Biological rhythmicity in expressed proteins of the marine dinoflagellate Lingulodinium polyedrum demonstrated by chronological proteomics. Biochem. Biophys. Res. Commun. 315:306-312.

Bockstahler, K. R. \& Coats, D. W. 1993. Grazing of the mixotrophic dinoflagellate Gymnodinium sanguineum on ciliate populations of Chesapeake Bay. Mar. Biol. 116:447-487.

Bradford, M. M. 1976. A rapid and sensitive method for the quantitation of microgram quantities of protein utilizing the principle of protein-dye binding. Anal. Biochem. 72:248-254.

Burkholder, J. M., Glibert, P. M. \& Skelton, H. M. 2008. Mixotrophy, a major mode of nutrition for harmful algal species in eutrophic waters. Harmful Algae 8:77-93.

Cerff, R. 1995. The chimeric nature of nuclear genomes and the antiquity of introns as demonstrated by GAPDH gene system. In Go, M. \& Schimmel, P. (Eds.) Tracing Biological Evolution in Protein and Gene Structures. Elsevier, Amsterdam, pp. 205-227.

Chan, L. L., Hodgkiss, I. J., Lu, S. \& Lo, S. C. -L. 2004. Use of two-dimensional gel electrophoresis proteome reference maps of dinoflagellates for species recognition of causative agents of harmful algal blooms. Proteomics 4:180-192.

Chan, L. L., Lo, S. C. -L. \& Hodgkiss, I. J. 2002. Proteomic study of a model causative agent of harmful red tide, Proro- 
centrum triestinum I: optimization of sample preparation methodologies for analyzing with two-dimensional electrophoresis. Proteomics 2:1169-1186.

Chan, L. L., Sit, W. -H., Lam, P. K. -S., Hsieh, D. P. H., Hodgkiss, I. J., Wan, J. M. -F., Ho, A. Y. -T., Choi, N. M. -C., Wang, D. -Z. \& Dudgeon, D. 2006. Identification and characterization of a "biomarker of toxicity" from the proteome of the paralytic shellfish toxin-producing dinoflagellate Alexandrium tamarense (Dinophyceae). Proteomics 6:654-666.

Fothergill-Gilmore, L. A. \& Michels, P. A. 1993. Evolution of glycolysis. Prog. Biophys. Mol. Biol. 59:105-235.

Guillard, R. R. L. \& Ryther, J. H. 1962. Studies of marine planktonic diatoms. I. Cyclotella nana Hustedt and Detonula confervacea (Cleve) Grun. Can. J. Microbiol. 8:229-239.

Harris, J. I. \& Waters, M. 1976. Glyceraldehyde-3-phosphate dehydrogenase. In Boyer, P. D. (Ed.) The Enzymes. 3rd ed. Academic Press, New York, pp. 1-49.

Jacobson, D. M. \& Anderson, D. M. 1996. Widespread phagocytosis of ciliates and other protists by marine mixotrophic and heterotrophic thecate dinoflagellates. J. Phycol. 32:279-285.

Jeong, H. J. 1999. The ecological roles of heterotrophic dinoflagellates in marine planktonic community. J. Eukaryot. Microbiol. 46:390-396.

Jeong, H. J., Yoo, Y. D., Park, J. Y., Song, J. Y., Kim, S. T., Lee, S. H., Kim, K. Y. \& Yih, W. H. 2005. Feeding by the phototrophic red-tide dinoflagellates: five species newly revealed and six species previously known to be mixotrophic. Aquat. Microb. Ecol. 40:133-150.

Kim, G. H., Shim, J. B., Klochkova, T. A., West, J. A. \& Zuccarello, G. C. 2008. The utility of proteomics in algal taxonomy: Bostrychia radicans/B. moritziana (Rhodomelaceae, Rhodophyta) as a model study. J. Phycol. 44:1519-1528.
NCBI. 2011. GenBank. Available from: http//www.ncbi.nlm. nih.gov. Accessed Feb 20, 2011.

O'Farrell, P. H. 1975. High resolution two-dimensional electrophoresis of proteins. J. Biol. Chem. 250:4007-4021.

Seong, K. A, Jeong, H. J., Kim, S., Kim, G. H. \& Kang, J. H. 2006. Bacterivory by co-occurring red-tide algae, heterotrophic nanoflagellates, and ciliates. Mar. Ecol. Prog. Ser. 322:85-97.

Shevchenko, A., Wilm, M., Vorm, O. \& Mann, M. 1996. Mass spectrometric sequencing of proteins from silverstained polyacrylamide gels. Anal. Chem. 68:850-858.

Sirover, M. A. 1999. New insights into an old protein: the functional diversity of mammalian glyceraldehyde3-phosphate dehydrogenase. Biochim. Biophys. Acta 1432:159-184.

Skovgaard, A. 1996. Engulfment of Ceratium spp. (Dinophyceae) by the thecate photosynthetic dinoflagellate Fragilidium subglobosum. Phycologia 35:490-499.

Smayda, T. J. 1997. Harmful algal blooms: their ecophysiology and general relevance to phytoplankton blooms in the sea. Limnol. Oceanogr. 42:1137-1153.

Spurr, A. R. 1969. A low-viscosity epoxy resin embedding medium for electron microscopy. J. Ultrastruct. Res. 26:3143.

Stoecker, D. K. 1999. Mixotrophy among dinoflagellates. J. Eukaryot. Microbiol. 46:397-401.

Wang, D. -Z., Lin, L., Chan, L. L. \& Hong, H. -S. 2009. Comparative studies of four protein preparation methods for proteomic study of the dinoflagellate Alexandrium sp. using two-dimensional electrophoresis. Harmful Algae 8:685-691.

Wong, P. -F., Tan, L. -J., Nawi, H. \& AbuBakar, S. 2006. Proteomics of the red alga, Gracilaria changii (Gracilariales, Rhodophyta). J. Phycol. 42:113-120. 